\title{
Diagnostyka postaci naczyniowo-nerwowej zespołu wibracyjnego - przegląd metod badawczych
}

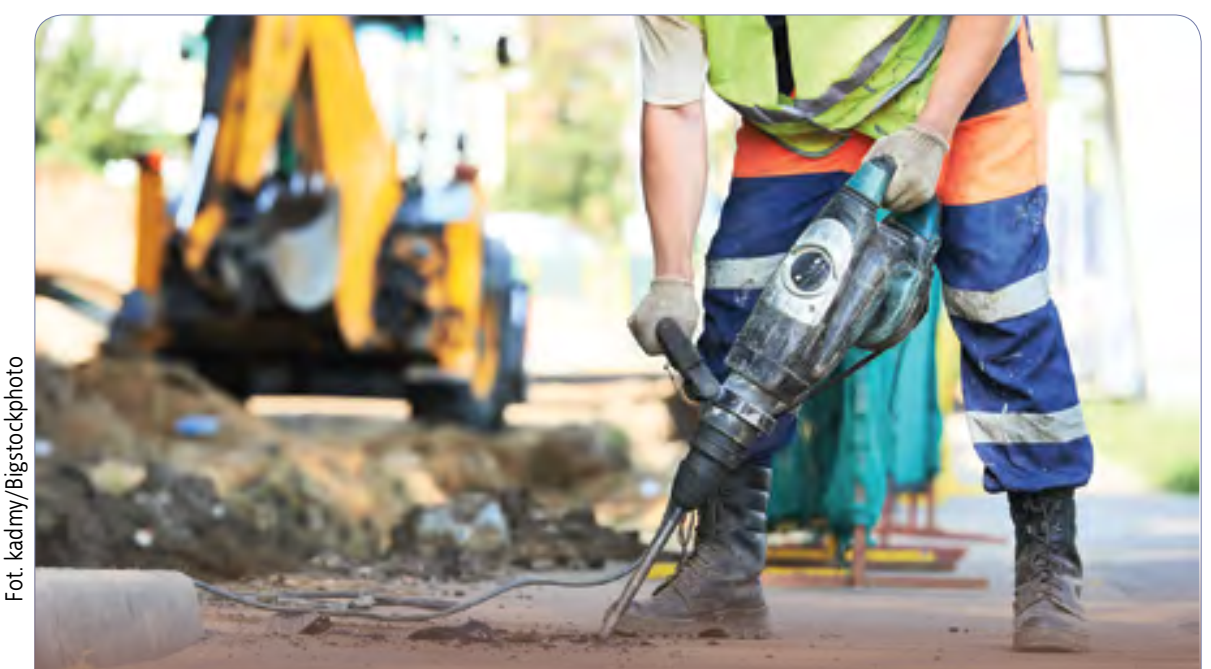

Długotrwała ekspozycja człowieka na drgania przenoszone przez kończyny górne wiąże się ze zwiększonym ryzykiem rozwoju dolegliwości ze strony układu naczyniowego, nerwowego i kostno-stawowego. Zespół tych objawów nazywany jest zespołem wibracyjnym (chorobą wibracyjną). W praktyce tę chorobę niejednokrotnie rozpoznaje się dopiero w zaawansowanym stadium rozwoju, kiedy u chorego pracownika doszło do obniżenia zdolności do pracy i upośledzenia wykonywania czynności dnia codziennego. Jest więc niezwykle istotne, aby pracowników zatrudnionych w warunkach narażenia na drgania przenoszone przez kończyny górne poddawać badaniom okresowym, które zwiększają szanse na wczesne wykrycie choroby i w konsekwencji pozwalają zapobiec powstawaniu nieodwracalnych zmian. Celem artykułu jest przybliżenie czytelnikowi metod badawczych mających zastosowanie w diagnostyce postaci naczyniowo-nerwowej zespołu wibracyjnego.

Słowa kluczowe: drgania przenoszone przez kończyny górne, postać naczyniowo-nerwowa zespołu wibracyjnego, próba oziębienia, termometria skórna, palestezjometria

Diagnosis of the neurovascular form of vibration syndrome - review of testing methods Prolonged exposure of humans to local vibration is associated with an increased risk of developing vascular, nervous, and musculoskeletal complaints. This syndrome is called vibration syndrome (vibration sickness). In practice, the disease is often diagnosed only at an advanced stage, when the worker's ability to work and perform daily activities is impaired. It is therefore extremely important that workers exposed to local vibrations undergo periodic examinations that increase the chances of early detection of the disease and, consequently, prevent the development of irreversible changes. The purpose of this article is to familiarize the reader with the testing methods applicable in the diagnosis of the neurovascular form of vibration syndrome. Keywords: local vibration, neurovascular form of vibration syndrome, cold test, skin thermometry, palesthesiometry

\section{Wstęp}

Na zagrożenia związane z drganiami mechanicznymi, przenoszonymi przez kończyny górne, narażonych jest w Polsce ok. 20 tys. osób, które wykonują różne zawody i pracują w różnych branżach [1]. Najliczniejszą grupę źródeł drgań przenoszonych przez kończyny górne w środowisku pracy stanowią zmechanizowane narzędzia wibracyjne, trzymane lub prowadzone rękami. Obecnie są one powszechnie wykorzystywane niemal we wszystkich dziedzinach ludzkiej aktywności, zwłaszcza w przemyśle wydobywczym, maszynowym, stoczniowym, przetwórczym, w budownictwie, hutnictwie, leśnictwie i rolnictwie [1]. Te narzędzia znacznie ułatwiają i przyspieszają wykonywanie różnorodnych czynności, ale jednocześnie intensywność drgań wytwarzanych na ich rękojeściach czy uchwytach jest w wielu przypadkach tak duża, że eksploatacja tego sprzętu stwarza zagrożenie dla zdrowia operatorów [2]. Z punktu widzenia rozwoju zmian chorobowych niezwykle istotne znaczenie ma rodzaj użytkowanych narzędzi wibracyjnych. Z badań wynika, że u niektórych pracowników nie obserwuje się objawów chorobowych mimo bardzo dużych ekspozycji na drgania przenoszone przez kończyny górne [3]. Z kolei takie urządzenia, jak pneumatyczne ubijaki formierskie czy pilarki z piłą łańcuchową, zalicza się do najbardziej szkodliwych źródeł drgań miejscowych w przemyśle.

Celem artykułu jest przybliżenie czytelnikowi metod badawczych mających zastosowanie w diagnostyce postaci naczyniowo-nerwowej zespołu wibracyjnego, w tym prostych metod, stosowanych przez badającego lekarza, jak i bardziej skomplikowanych, wymagających odpowiedniego zaplecza aparaturowego i wykwalifikowanego personelu.

\section{Zespół wibracyjny}

Systematyczna ekspozycja człowieka na drgania przenoszone przez kończyny górne może zaburzać prawidłowe funkcjonowanie 
organizmu i prowadzić do rozwoju choroby zawodowej - zespołu wibracyjnego (choroby wibracyjnej) [4]. Według Centralnego Rejestru Chorób Zawodowych Instytutu Medycyny Pracy w Łodzi w 2019 r. zespół wibracyjny stwierdzono w dziewięciu przypadkach, co stanowiło 0,4\% wszystkich rejestrowanych chorób zawo dowych. Dla porównania w 2018 r. stwierdzono 17 przypadków choroby [5]. Pomimo tendencji spadkowej dotyczącej liczby zachorowań pro blem zespołu wibracyjnego nie może być lek ceważony. Rozwój tej choroby jest podstępny - jej pierwsze objawy często nie zwracają uwag chorego, natomiast w miarę upływu czasu działania wibracji dochodzi do zaawansowanych, często nieodwracalnych zmian chorobowych.

Najbardziej wrażliwe na drgania przenoszone przez kończyny górne są układy: nerwowy, krwionośny i kostno-stawowy. W związku z tym wyróżnia się kilka postaci zespołu wibracyjnego (w zależności od tego, który układ dominuje w obrazie chorobowym): postać naczyniowo -nerwową, postać kostno-stawową i postać mieszaną (charakteryzującą się objawami wspólnymi dla obu wymienionych wcześniej postaci) [6].

Najczęściej występuje postać naczynio wo-nerwowa z napadowymi zaburzeniami krążenia krwi w palcach rąk, czego objawem jest blednięcie opuszek palców (tzw. choroba białych palców) - fot. 1. Napadowe blednięcie zazwyczaj jest wyzwalane ekspozycją na zimno więc dolegliwości nasilają się w chłodnej porze roku, natomiast latem słabną lub całkowicie ustępują [7].

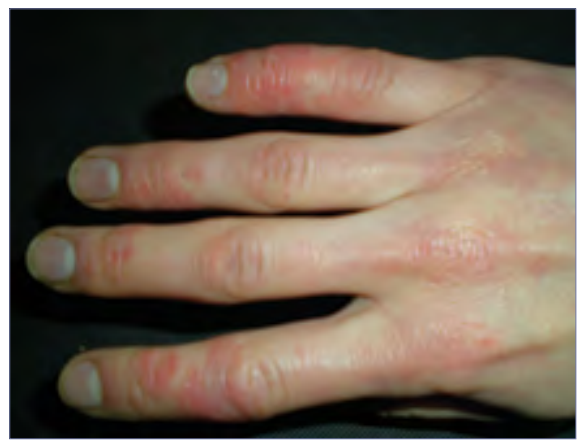

Fot. 1. W przebiegu zespołu wibracyjnego może występować blednięcie palców (fot. Urfavejerzeygrl)

Photo 1. Whiteness of fingers may occur in the course of the vibration syndrome (photo: Urfavejerzeygrl)

Z czasem dolegliwości pojawiają się częściej, niezależnie od pory roku, a ogrzewanie rąk nie przynosi poprawy. W zaawansowanych przypadkach powtarzające się i nasilone napady blednięcia palców mogą doprowadzić w skórze opuszek palców rąk do zmian w postaci owrzodzeń lub martwicy. Zmianom naczyniowym towarzyszą zmiany neurologiczne, takie jak zaburzenia czucia dotyku, temperatury i wibracji, a także dolegliwości w postaci drę twienia i mrowienia palców oraz całych kończyn górnych. Podczas napadu blednięcia palców pracownik może doświadczać całkowitej utraty czucia dotyku i sprawności manualnej, co zakłóca czynności w pracy, a niekiedy nawet jest przyczyną wypadku [8].

Pierwsze objawy zespołu wibracyjnego mogą wystąpić już po kilku miesiącach pracy w narażeniu na drgania przenoszone przez kończyny górne, jednak poważniejsze symp tomy zazwyczaj występują po ok. trzech latach Zignorowanie początkowych objawów i dalsza ekspozycja na drgania powodują, że choroba postępuje. Oprócz obniżenia zdolności do pracy dochodzi również do upośledzenia wykonywania czynności dnia codziennego, dlatego kluczowe wydaje się przestrzeganie terminów badań okresowych i jak najszybsze odsunięcie pracownika od źródeł drgań mechanicznych w środowisku pracy w przypadku stwierdzenia nieprawidłowości [9].

Obowiązujące wytyczne co do diagnostyki choroby wibracyjnej są zawarte w rozporządzeniu w sprawie przeprowadzania badań lekarskich pracowników, zakresu profilak tycznej opieki zdrowotnej nad pracownikami oraz orzeczeń lekarskich wydawanych do celów przewidzianych w kodeksie pracy [10] Zgodnie z tymi przepisami zaleca się, aby podczas badań wstępnych i okresowych przeprowadzać ogólną ocenę lekarską ze zwróceniem uwagi na układ naczyniowy, nerwowy i kostny w obrębie kończyn górnych. W diagnostyce postaci naczyniowo-nerwowej ważne miejsce - oprócz charakterystycznego wywiadu chorobowego i zawodowego - zajmują badania pomocnicze. Według rozporządzenia do obligatoryjnych badań pomocniczych w diagnostyce postaci naczyniowo-nerwowej zespołu wibracyjnego należy próba oziębiania z termome trią skórną i próbą uciskową. Pierwsze badanie okresowe należy wykonać po roku pracy w narażeniu na drgania przenoszone przez kończyny górne, a następnie należy je powtarzać co trzy lata.

\section{Badania pomocnicze w diagnostyce postaci naczyniowo-nerwowej zespołu wibracyjnego}

Panel badań pomocniczych wykorzystywanych w diagnostyce postaci naczyniowo-nerwowej zespołu wibracyjnego jest szeroki. Obejmuje on zarówno bardzo proste metody, stosowane przez badającego lekarza, jak i te bardziej skomplikowane, wymagające odpo wiedniego specjalistycznego wyposażenia aparaturowego i personelu.

Do oceny zmian naczyniowych w przebiegu zespołu wibracyjnego służą przede wszystkim metody obligatoryjne, tj. próba oziębiania z termometrią skórną i próbą uciskową, ale też badania nieuwzględnione w rozporządzeniu, m.in. opisane dalej: próba białej plamy, próba Pala oraz kapilaroskopia włośniczek wałów paznokciowych. Z kolei badaniem po- mocniczym do oceny zmian neurologicznych w zespole wibracyjnym jest palestezjometria, która przed nowelizacją rozporządzenia była obligatoryjna w diagnostyce zespołu wibracyjnego. Mniej popularne jest natomiast badanie elektroneuromiograficzne.

\section{Badania pomocnicze do oceny zmian naczyniowych}

W próbie oziębienia z termometrią skórną porównywane są wyjściowe wyniki temperatury skóry palców rąk z wynikami uzyskanymi po zastosowaniu prowokacji zimnem. Temperatura skóry palców rąk wiąże się bezpośrednio z przepływem krwi w dystalnych odcinkach kończyn Prowokacja zimnem pozwala na ujawnienie początkowych zaburzeń reaktywności drobnych naczyń obwodowych, które są tym wyraźniejsze, im niższa jest stosowana temperatura chłodzenia rąk. Wielkość reakcji naczynioruchowych, wyrażana wartością temperatury skóry palców, może być oceniana podczas oziębiania rąk lub w czasie odnowy na podstawie porównania z wartością wyjściową [11]. W Polsce próba oziębienia połączona z termometrią skórną polega na zanurzaniu rąk w wodzie o temperaturze $+14^{\circ} \mathrm{C}$, po uprzednim pomiarze temperatury skóry grzbietowych powierzchni paznokciowych paliczków palców rąk II-V za pomocą termometru bezdotykowego. Podczas termicznej próby czynnościowej badani przyjmują komfortową pozycję siedzącą i zanurzają obie dłonie w chłodnej wodzie, znajdującej się w plastikowym naczyniu, nie dotykając jego krawędzi. Następnie, po wyjęciu rąk z wody, obserwuje się ewentualne zmiany barwy skóry, a następnie po szybkim osuszeniu papierowym ręcznikiem wykonywane są pomiary ciepłoty skóry palców II, III i IV w pierwszej minucie oraz co pięć minut do uzyskania wyjściowych wartości temperatury. Za prawidłowy wynik odnowy przyjmuje się powrót temperatury do stanu wyjściowego w czasie nieprzekraczającym 10 minut, za wydłużenie odnowy - powrót temperatury do stanu wyjściowego po 11-20 minutach, a za brak odnowy - brak powrotu temperatury do stanu wyjściowego po upływie 20 i więcej minut. Natychmiast po wyjęciu rąk z wody można wykonać dodatkowo próbę uciskową Levis-Prusika. Polega ona na krótkim uciśnięciu opuszki IV palca - jako wynik dodatni przyjmuje się utrzymywanie się zblednięcia powyżej pięciu sekund [12].

Do oceny zaburzeń naczyniowych w zespole wibracyjnym stosuje się także inne, nieobligatoryjne badania, np. próbę białej plamy czy kapilaroskopię włośniczek wałów paznokciowych.

Próba białej plamy polega na tym, że badany przez pięć sekund silnie zaciska pięść, a następnie szybko wyprostowuje palce. Za wynik dodatni, świadczący o tendencjach skurczowych naczyń krwionośnych, uznaje się obecność plamistego zblednięcia skóry dłoni i palców, które utrzymuje się ponad 10 sekund. 
Kapilaroskopia włośniczek wałów paznokciowych jest przydatna do oceny zaawansowanych zaburzeń naczyniowych, która nie jest łatwa ze względu na dużą rozpiętość tzw. granicy normy oraz brak obrazu kapilarosko powego charakterystycznego wyłącznie dla naczyniowo-nerwowej postaci zespołu wibracyjnego. Metoda znajduje więc zastosowanie nie tyle w diagnostyce, co w rokowaniu, gdyż wielokrotne obserwacje mogą wskazywać na pogłębianie się zaburzeń naczyniowych [12].

Do rzadziej stosowanych metod można zaliczyć m.in. termowizję (termografię) i fotopletyzmografię. Technika termowizyjna - całkowicie nieinwazyjna i bezdotykowa - pozwala diagno zować choroby różnego pochodzenia (fot. 2). Wiadomo, że powierzchniowa temperatura ciała jest ściśle związana z charakterem podskórnego przepływu krwi i procesami metabolicznymi tkanek, a oddawane promieniowanie podczerwone może odzwierciedlać zwiększony lub zmniejszony przepływ krwi w danym obszarze. W związku z tym założono, że obraz termograficzny pozwoli dostrzec zmiany ukrwienia związane ze zmianami fizjologicznymi tkanki w badanym obszarze. Termografię można wykorzystać do wczesnego wykrywania choroby wibracyjnej oraz rozpoznawania jej etapu [13].

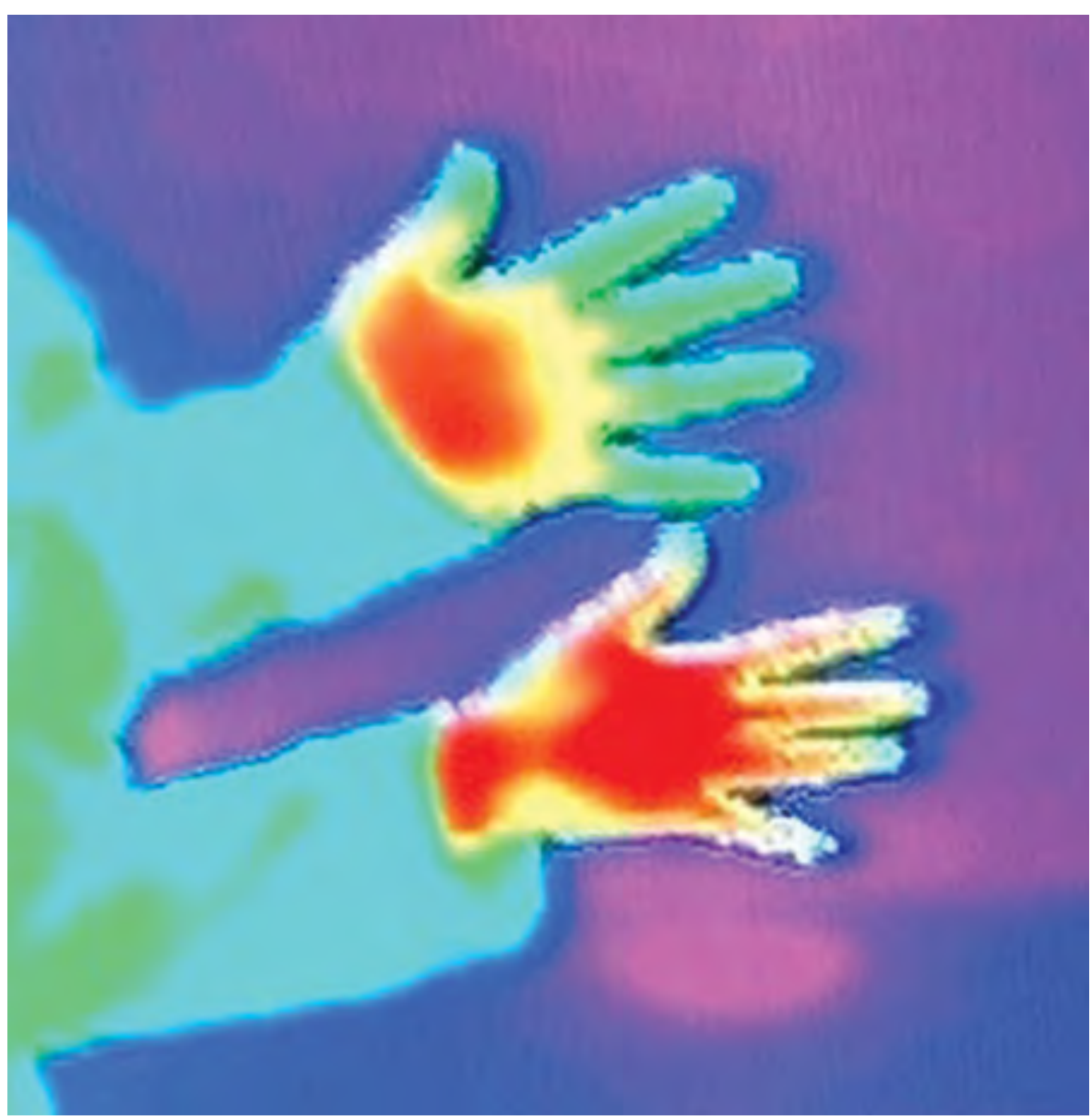

Fot. 2. Obraz termowizyjny rąk: widoczne zaburzenia ukrwienia palców ręki lewej (fot. Joe m2013)

Photo 2. Thermal image of hands: blood circulation disorders in the fingers of the left hand (photo: Joe m2013) pracy, a to oznacza możliwość szybkiej identyfikacji osób, u których występują zmiany naczyniowe, oraz podjęcia efektywniejszych działań profilaktycznych.

\section{Badania pomocnicze do oceny zmian neurologicznych}

Palestezjometria (badanie czucia wibracji) stanowi przydatne narzędzie do ilościowej oceny zaburzeń neurologicznych, indukowanych przez zespół wibracyjny. Polega na wyznaczaniu najmniejszej wyczuwalnej amplitudy ruchu drgającego poprzez pobudzanie mechanoreceptorów znajdujących się na opuszkach palców rąk. Badanie wykonuje się w cichym pomieszczeniu, w którym panuje temperatura $22-24^{\circ} \mathrm{C}$. Przed badaniem należy dokonać pomiaru ciepłoty opuszek palców termometrem bezdotykowym - wynik pomiaru nie powinien być mniejszy niż $27^{\circ} \mathrm{C}$ (im niższa temperatura opuszek, tym wyższy próg czucia). Podczas badania pacjent trzyma rękę na urządzeniu, dotykając sondy drgającej. Pomiar wykonuje się metodą wstępującą, tzn. poziom drgań narasta, a pacjent sygnalizuje moment pojawienia się czucia drgań. W ten sposób zostaje wyznaczony najmniejszy (progowy) poziom drgań, które badany odczuwa przy jednorazowym zaprezentowaniu bodźca. Metoda stosowana w Polsce zakładała badanie progów czucia przy częstotliwościach wysokich - z zakresu $63-500 \mathrm{~Hz}$. Wynik stanowił średnią arytmetyczną wysokości progów czucia wibracji przez palce II, III i IV w zakresie 250, 400 i $500 \mathrm{~Hz}$ [16].

Z kolei w opracowanej w 2001 r. normie ISO 13091-1 preferowane są niskie częstotliwości drgań (maksymalnie do $160 \mathrm{~Hz}$ ) [17]. Norma zakłada badanie za pomocą bodźca ciągłego, podawanego metodą Bekesy'ego, polegającą na wyznaczeniu średniego progu czucia z kilku pomiarów dla wzrastającego i malejącego w sposób ciągły bodźca w zakresie 75-150 dB [18].

Oprócz palestezjometrii do oceny zaburzeń neurologicznych może służyć badanie elektroneuromiograficzne - badanie przewodnictwa we włóknach czuciowych i ruchowych nerwów obwodowych (pośrodkowego i promieniowego) kończyn górnych. W zespole wibracyjnym najczęściej dochodzi do zwolnienia przewodnictwa we włóknach czuciowych nerwów obwodowych [19].

\section{Podsumowanie}

Wyniki badań naukowych wskazują, że pomimo przerwania narażenia zawodowego na drgania przenoszone przez kończyny górne rokowanie w przypadku postaci naczyniowo-nerwowej zespołu wibracyjnego zazwyczaj jest złe. Całkowite ustąpienie zmian chorobowych jest możliwe tylko u osób, u których zespół wibracyjny został rozpoznany we wczesnej fazie rozwoju, u osoby w młodym wieku i po krótkim okresie narażenia [20]. Dlatego jest niezmiernie 
ważne, aby osoby pracujące w warunkach narażenia na drgania mechaniczne, $w$ tym osoby samozatrudniające się, systematycznie poddawały się badaniom okresowym.

Dzięki wczesnej diagnostyce choroby i wykorzystaniu dostępnych metod pomocniczych moż na zapobiec rozwojowi zmian zaawansowanych, będących przyczyną obniżenia zdolności do pracy i znacznego stopnia niepełnosprawności.

\section{BIBLIOGRAFIA}

[1] HARAZIN, B., ZIELIŃSKI, G. Zawodowa ekspozycja na miejscowe wibracje w Polsce. Medycyna Pracy. 2004, 55(3): 217-225.

[2] KOTON, J., HARAZIN, B. Skutki zdrowotne zawodowego narażenia na drgania miejscowe. Warszawa: CIOP, 2000.

[3] HARAZIN, B. Zagrożenie zdrowia wywołane działaniem drgań mechanicznych. Sosnowiec: IMPiZŚ, 2000; Drgania mechaniczne. Sosnowiec: IMPiZŚ, 1996

[4]HEAVER, C., GOONETILLEKE, K.S., FERGUSON, H. SHIRALKAR, S. Hand-arm vibration syndrome: a common occupational hazard in industrialized countries. Journal of Hand Surgery (European Volume). 2011, 36(5): 354-363.

[5] ŚWIĄTKOWSKA, B., HANKE, W., SZESZE NIA-DABROWSKA, N. Choroby zawodowe w Polsce w 2019 r. Łódź: Instytut Medycyny Pracy im. prof. dr. J. Nofera w Łodzi, 2020.

[6] ŚWIERCZYŃSKA-MACHURA, D. Choroba wibracyjna. Medycyna po Dyplomie. 2015, 5

[7] HOUSE, R., KRAJNAK, K., JIANG, D. Factors affecting finger and hand pain in workers with HAVS Occupational Medicine. 2016, 66(4): 292-295.

[8] MALINOWSKA-BOROWSKA, J., SOCHOLIK, V., HARAZIN, B. Stan zdrowia pracowników leśnych narażonych na hałas i wibracje miejscowe wytwarzane przez piły łańcuchowe. Medycyna Pracy. 2012, 63(1): 19-29.

[9] BUDD, D., HOLNESS, D.L., HOUSE, R. Functional limitations in workers with hand-arm vibration syndrome (HAVS). Occupational Medicine. 2018, 68(7): 478-481.

[10] Rozporządzenie Ministra Zdrowia z dnia 12 listopada 2020 r. zmieniające rozporządzenie w sprawie przeprowadzania badań lekarskich pracowników, zakresu profilaktycznej opiekizdrowotnej nad pracownikami oraz orzeczeń lekarskich wydawanych do celów przewidzianych w Kodeksie pracy (Dz.U. poz. 2131)

[11] International Organization for Standardization: Mechanical vibration and shock-Cold provocation tests for the assessment of peripheral vascular function-Part 1: Measurement and evaluation of finger skin temperature. International Standard ISO 14835-1:2016 Szwajcaria, Genewa 2016.

[12] LANGAUER-LEWOWICKA, H., STACHURA, A Zespół wibracyjny. [W:] K. Marek. Choroby zawodowe. Warszawa: Wydawnictwo Lekarskie PZWL, 2001, s. 327-350.

[13] PIETRZAK, P., PIOTROWICZ, M., WOŹNIAKOWSKI, B., GRECKI, M. Zastosowanie termografii W diagnostyce chorych z podejrzeniem choroby Reynaud. Mikroelektronika i Informatyka: Prace Naukowe. 2004, 4: 137-142.

[14] NJOUM, H., KYRIACOU, P.A. Photoplethysmography: Towards a non-invasive pressure measurement technique. Conference Proceedings IEEE Engineering in Medicine and Biology Society. 2016, pp. 611-614.

[15] WU, H.T., et al. Assessment of Vascular Health With Photoplethysmographic Waveforms From the Fingertip. IEEE Journal of Biomedical and Health Informatics. 2017, 21(2): 382-386.

[16] SZCZYRBA, S., BIENIASZEWSKI, L. Ilościowe badanie czucia wibracji i temperatury - ocena powtarzalności metody. Annales Academiae Medicae Gedanensis. 2007, 37: 123-136.

[17] International Organization for Standardization: Mechanical vibration - Vibrotactile perception thresholds for the assessment of nerve dysfunction - Part 1: Methods of measurement at the fingertips. ISO 13091-1:2001. Szwajcaria, Genewa 2001.

[18] HARAZIN, B., KUPROWSKI, J., HARAZIN-LECHOWSKA, A. Porównanie u kobiet progów czucia wibracji wyznaczonych dwiema psycho fizycznymi metodami pomiarowymi. Medycyna Pracy. 2004, 55 (4): 321-328.

[19] YE, Y., GRIFFIN, M.J. Assessment of thermotactile and vibrotactile thresholds for detecting sensorineural components of the hand-arm vibration syndrome (HAVS). International Archives of Occupational and Environmental Health. 2018, 91(1): 35-45

[20] SAUNI, R., et al. Work disability after diagnosis of hand-arm vibration syndrome. International Archives of Occupational and Environmental Health. 2015, 88(8): 1061-1068

Opracowano i wydano na podstawie wyników V etapu programu wieloletniego "Poprawa bezpieczeństwa i warunków pracy", finansowanego w zakresie badań naukowych i prac rozwojowych ze środków Narodowego Centrum Badań i Rozwoju (projekt nr II.PB.14 pt. „Ocena przydatności łączonych metod badawczych we wczesnej diagnostyce postaci naczyniowo-nerwowej zespołu wibracyjnego wśród osób zatrudnionych w narażeniu na wibrację miejscowq"). Koordynator programu: Centralny Instytut Ochrony Pracy - Państwowy Instytut Badawczy.

\section{BEPTEBEFISTIW I : $/ \mathrm{H}^{\prime}$ nauka i praktyka}

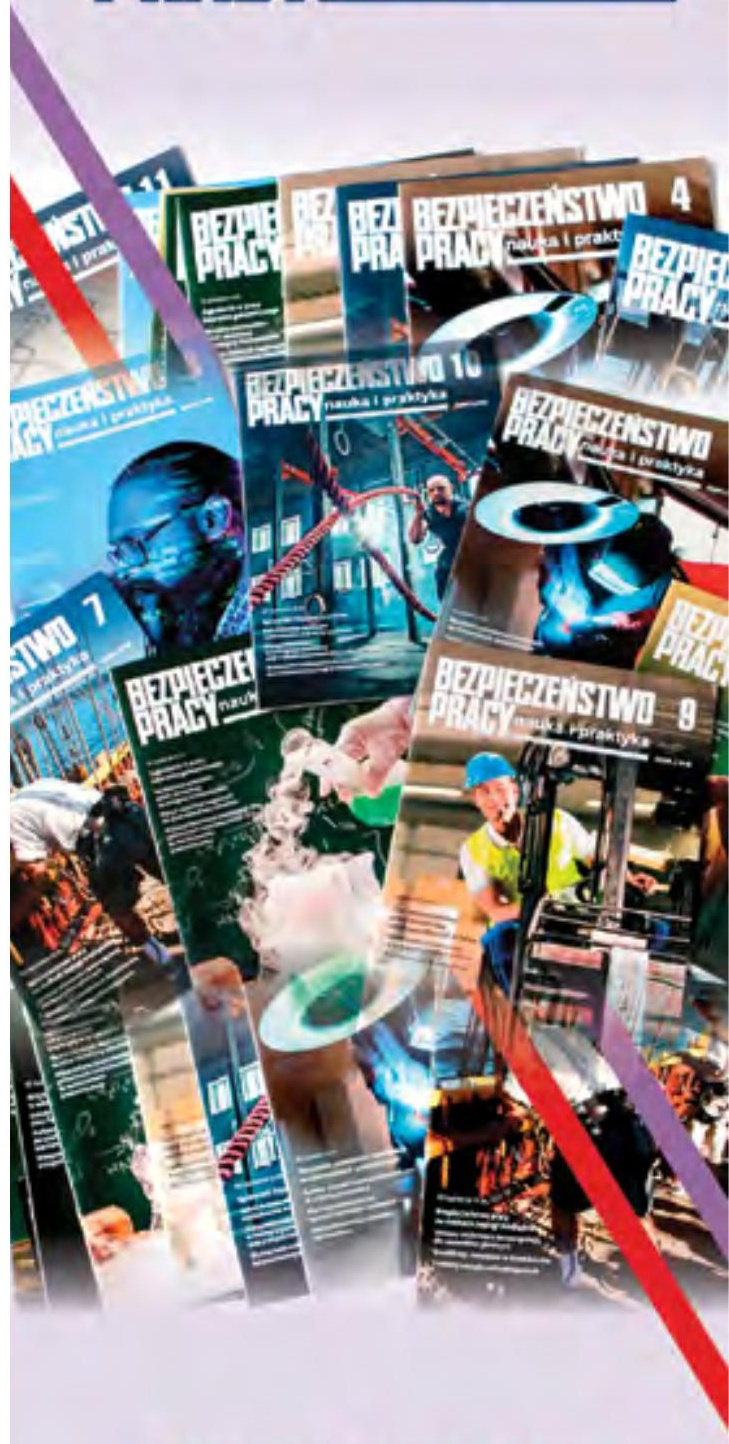

WWW.CIOP.PL

\author{
e-mail: \\ bpredakcja@ciop.pl
}

